How to cite this article:

Huong, Y. S., \& Khoo, Y. H. (2019). Human rights, state sovereignty, and the death penalty: Indonesia's diplomacy approach on Bali Nine. Journal of International Studies, 15, 1-20. https://doi.org/10.32890/jis2019.15.1

\title{
Human Rights, State Sovereignty, and the Death Penalty: Indonesia's Diplomacy Approach on Bali Nine
}

\author{
Yu Sin Huong \& ${ }^{1}$ Ying Hooi Khoo \\ Department of International and Strategic Studies \\ Faculty of Arts and Social Sciences, \\ University of Malaya, Malaya \\ ${ }^{1}$ Corresponding author: yinghooi@um.edu.my \\ DOI: https://doi.org/10.32890/jis2019.15.1
}

\begin{abstract}
The discrepancies in Indonesia's diplomatic approach on the death penalty for its people abroad and other nationalities at home have raised 'double standard' concerns. By looking into the factors affecting Indonesia's diplomatic approach to Australia using the case of Bali Nine, the study explored the rationale of the Indonesian government putting national interest over its human rights commitment despite the increased pressure on its death penalty practice in the debate between human rights and state sovereignty. This study used the interview method with two objectives. First, to investigate the factors influencing Indonesia's diplomatic approach to the Bali Nine case, and second, to explore the conflict between human rights and state sovereignty by drawing upon the theoretical framework on human rights and foreign policy as proposed by Jack Donnelly. The finding of this paper suggests that human rights interests are subordinated to other national interests in balancing the objectives of Indonesia's diplomacy on the drug-related death penalty practice.
\end{abstract}

Keywords: Death penalty, human rights, state sovereignty, Bali Nine, Indonesian foreign policy, Australia.

\section{Introduction}

The notion of human rights is observed in the preamble of the 1945 Indonesian Constitution $^{1}$, under the Pancasila principles. However, the ambiguous provisions of human rights in the Constitution, and the inconsistent local practice of human rights with military-led mass violence outbreak during the administrations of Sukarno (1945-1967) and Suharto (1967- 
1998) later on triggered a comprehensive human rights protection in Indonesia. ${ }^{2}$ During the transition democracy period between 1998 and 2004, the political instability and the deteriorated human rights situation in Indonesia prompted an opportunity for advancement of democracy and human rights. Along with the domestic political transformation, democracy and human rights agendas were envisioned in the Indonesian foreign policy. To raise its international credibility and global leadership status, Indonesia ratified eight out of nine international human rights treaties and was placed third in the ranking of states with the most ratified international human rights treaties in Southeast Asia.

As a strong human rights advocator in the region of Southeast Asia, the drug-related death penalty practice in Indonesia becomes incoherent with its Constitution, foreign policy objectives and obligations outlined in ratified international human rights treaties. In relation to the execution of foreign death row prisoners, Indonesia has constantly faced growing diplomatic tensions with other countries since the administration of Susilo Bambang Yudhoyono (2004-2014). 21-recorded executions were carried out in Indonesia during the Yudhoyono administration, including three foreign death row prisoners (Imparsial, 2010). Under the administration of his successor, Joko Widodo, or famously known as Jokowi, the number of death sentences and executions have increased. According to the Amnesty International Global Report: Death Sentences and Executions 2018, Indonesia recorded at least 48 death sentences from January to December 2018 while at least 308 people were known to be under the sentence of death at the end of 2018. The report further pointed out, "Of the 48 recorded new death sentences, 39 (81\%) were imposed for drug-related offences; eight (17\%) for murder; and one (2\%) for a terrorism-related crime. $15(31 \%)$ were imposed on foreign nationals, all for drug-related offences".

However, the death penalty practice in Indonesia is in conflict with the diplomatic efforts taken by the Indonesian government to prevent execution of its citizens abroad. Indonesia propagated its moral obligation by criticising other states on executing Indonesians judicially such as in the case of the Indonesian maid, Ruyati binti Sapubi (Coca, 2015). ${ }^{3}$ This led to the criticism of the Indonesian government practising 'double standard' in its diplomatic approach to the death penalty. The discrepancies in the human rights promotion for its people abroad and other nationalities at home have raised concerns over human rights obligations in Indonesia.

Although Indonesia has ratified the International Covenant on Civil and Political Rights (ICCPR), and not the Second Optional Protocol to the $\mathrm{ICCPR}^{4}$ in relation to the abolition of the death penalty, the Indonesian government still has the responsibility to abide by Article 6 of the ICCPR that strictly stresses that the death penalty may only be imposed for the 'most serious crimes'. The requirement of the 'most serious crimes' has established state obligations in limiting their practice of the death penalty for crimes with the intention to kill causing death (International Commission against the Death Penalty, 2013). Through local legal provisions for human rights and ratification of international human rights treaties, the obligations towards its citizens and the international society in promoting human rights within its boundaries were established. 
Forsythe (2011) argued that states are more likely to disregard human rights if the cost is greater. States, driven primarily by security and economy interests, are more likely to misuse and neglect human rights' interests in the foreign policy when it is in conflict with other national interests. In response to the growing tension on the death penalty issue, the Indonesian government denied such criticism by emphasizing the 'drug emergency' as one of the main issues in Indonesia, and highlighting its duties in safeguarding the interest of its people (McRae, 2015). In Indonesia, drug-related crimes are portrayed as a main threat to its national security. Being a strong retentionist state, Indonesia regarded the death penalty as a necessary form of crime deterrence to maintain the order of the society (Afriansyah, 2015).

The death penalty practice in Indonesia is complex as it involves not only the legal framework, but also the political factor, public pressure, and religious beliefs. Local anti-drug organisations and religious groups offer strong support for the death penalty. Communities in Indonesia are heavily exposed to the anti-narcotics propaganda, which constructed a strong public opinion in supporting the death penalty in Indonesia. As the biggest Muslim democratic state, there is also strong support for the death penalty from the Muslim community as the death penalty practice is accepted based on their religious teachings (Parlina, 2014). The death penalty practice is strongly supported at the domestic level as majority of Indonesians agreed with the need of the death penalty law in the Indonesian legal system (Basuki, Dwifatma, Fransiska, \& Sulaiman, 2015).

Based on this, the international human rights standards are perceived as a challenge to the sovereignty (Clunan, 2009). Any attempt to interfere with state's domestic human rights affairs is regarded as violating the principle of non-interference that forms part of the basis of the state sovereignty in the international system. On that ground, human rights obligations and state sovereignty have been in constant tension, as demonstrated in the Bali Nine case. Indonesia upheld its state sovereignty to defend its stance in executing death row offenders in its territory boundaries and its self-determination in implementing the death penalty (Afriansyah, 2015). This paper intends to present a bigger picture of the Indonesian diplomatic approach when it comes to the human rights issue by examining the diplomatic efforts and reactions of the Indonesian governments in response to the Bali Nine case.

This paper is qualitative in nature. For primary sources, data was collected through interviews. Interview questions were prepared and given to each interviewee according to their areas of expertise. The interviewees were divided into three groups. The first group included those who worked for non-governmental organisations (NGOs) involved in the issue of death penalty. It was important to gain fresh data and the latest news on this field as these people worked on the ground. The second group consisted of legal experts in Indonesia who worked on cases related to the death penalty. They provided insights into the legal system of Indonesia. The third group was made up of academic scholars who worked on topics related to the death penalty and human rights in the Indonesian foreign policy. The identity of each interviewee was kept confidential and anonymous if desired by the interviewee to 
prevent any potential harm. Additionally, secondary sources such as books, journal articles, electronic articles, videos, documentaries, government official statements and documents, NGOs' reports and statistics, and newspaper articles contributed to the data collection process. The news reports of the Bali Nine case from the trusted press sources of both Indonesia and Australia were particularly useful. Videos and documentaries by established sources were retrieved such as from the YouTube. These methods were used simultaneously in order to corroborate the findings to increase the credibility and persuasiveness of the results, in accordance with the concept of source triangulation.

The large number of executions in Indonesia during the reign of Jokowi cast doubts on the human rights condition in Indonesia and its effort to promote human rights. In an international society with higher credits for international human rights standards, Indonesian diplomatic approaches to the drug-related death penalty practice within its borders, such as balancing its national interests between human rights and state sovereignty, became significant to understand the perspective of a state towards international human rights standards. Based on this, this paper had two objectives. First, it investigated the factors influencing its diplomatic approaches to the Bali Nine case, and second, it explored the conflict between human rights and state sovereignty in this case.

\section{Diplomacy efforts and tensions on Bali Nine}

Since the administration of Jokowi in 2014, Indonesia's strong diplomatic responses to the Bali Nine case became the focus of the international society to understand human rights in the Indonesian foreign policy. Bali Nine was the name given to a group of nine Australians, namely Michael Czugaj, Renae Lawrence, Martin Stephens, Scott Rush, Myuran Sukumaran, Tan Duc Thanh Nguyen, Matthew Norman, Si Yi Chen and Andrew Chan. In 2005, they were convicted of heroin smuggling in Bali, Indonesia. Although the death sentence for drug trafficking was imposed based on judicial discretion in Indonesia, the Indonesian government's stern approach to drug-related crimes had led to the death penalty of Chan and Sukumaran, the ringleaders of Bali Nine. As an abolitionist state, the Australian government carried out numerous diplomatic initiatives to plead for clemency for the Bali Nine members.

As the death penalty for drug trafficking was non-mandatory in Indonesia, it provided avenues of appeal for the defendants to have reduced sentences. Furthermore, Indonesia, as a civil law state, "was not bound to a system of precedent or sentencing consistency" (Simandjuntak, 2015). This allowed the Bali Nine members to receive verdicts that were different from previous cases. Presidential clemency was available as a last resort for death row prisoners to either receive commutations or pardons. This had established the supremacy and legitimacy of the legal system. Throughout the legal proceedings, sentences delivered to the members of Bali Nine were relatively constant as shown in Table 1. 
The death sentences for Sukumaran and Chan as well as the life imprisonment for Stephens were upheld throughout the appeal (AAP, 2006). As for the others, sentencing changed at different levels of appeal proceedings due to the extent of consideration for national interests. There was limited consideration on human rights in sentencing. There was only one occasion when the panel of three judges reflected on the notion of human rights and the imposition of the death penalty that was only reserved for the 'most serious crimes' in their written declaration during the final appeal hearing of Chan and Sukumaran at the Denpasar District Court (AAP, 2011). Absence of consideration on the successful rehabilitation that was undergone by Chan and Sukumaran also undermined the use of successful rehabilitation as a bargain for reducing sentences on humanitarian grounds.

Table 1

Summary of Sentences for Bali Nine Members throughout 10 Years of Legal Process

\begin{tabular}{|c|c|c|c|c|c|c|}
\hline Names & Trial & $\begin{array}{l}\text { Bali High } \\
\text { Court } \\
\text { Appeal }\end{array}$ & $\begin{array}{l}\text { Supreme } \\
\text { Court } \\
\text { Appeal }\end{array}$ & $\begin{array}{l}\text { Judicial } \\
\text { Review }\end{array}$ & $\begin{array}{c}\text { Constitution } \\
\text { Court } \\
\text { Appeal }\end{array}$ & $\begin{array}{c}\text { Presidential } \\
\text { Clemency }\end{array}$ \\
\hline $\begin{array}{l}\text { Andrew } \\
\text { Chan }\end{array}$ & $\begin{array}{c}\text { Death } \\
\text { penalty }\end{array}$ & $\begin{array}{l}\text { Death } \\
\text { penalty }\end{array}$ & $\begin{array}{l}\text { Death } \\
\text { penalty }\end{array}$ & $\begin{array}{c}\text { Death } \\
\text { penalty }\end{array}$ & Rejected & Rejected \\
\hline $\begin{array}{l}\text { Myuran } \\
\text { Sukumaran }\end{array}$ & $\begin{array}{c}\text { Death } \\
\text { penalty }\end{array}$ & $\begin{array}{c}\text { Death } \\
\text { penalty }\end{array}$ & $\begin{array}{c}\text { Death } \\
\text { penalty }\end{array}$ & $\begin{array}{c}\text { Death } \\
\text { penalty }\end{array}$ & Rejected & Rejected \\
\hline Scott Rush & $\begin{array}{c}\text { Life } \\
\text { sentence }\end{array}$ & - & $\begin{array}{c}\text { Death } \\
\text { penalty }\end{array}$ & $\begin{array}{c}\text { Life } \\
\text { sentence }\end{array}$ & Rejected & Pending \\
\hline $\begin{array}{l}\text { Martin } \\
\text { Stephens }\end{array}$ & $\begin{array}{c}\text { Life } \\
\text { sentence }\end{array}$ & $\begin{array}{c}\text { Life } \\
\text { sentence }\end{array}$ & $\begin{array}{c}\text { Life } \\
\text { sentence }\end{array}$ & $\begin{array}{c}\text { Life } \\
\text { sentence }\end{array}$ & - & Pending \\
\hline $\begin{array}{l}\text { Michael } \\
\text { Czugaj }\end{array}$ & $\begin{array}{c}\text { Life } \\
\text { sentence }\end{array}$ & $\begin{array}{c}20 \text {-year } \\
\text { prison }\end{array}$ & $\begin{array}{c}\text { Life } \\
\text { sentence }\end{array}$ & $\begin{array}{c}\text { Life } \\
\text { sentence }\end{array}$ & - & Pending \\
\hline Si Yi Chen & $\begin{array}{c}\text { Life } \\
\text { sentence }\end{array}$ & $\begin{array}{c}20 \text {-year } \\
\text { prison }\end{array}$ & $\begin{array}{c}\text { Death } \\
\text { penalty }\end{array}$ & $\begin{array}{c}\text { Life } \\
\text { sentence }\end{array}$ & - & Pending \\
\hline $\begin{array}{l}\text { Mathew } \\
\text { Norman }\end{array}$ & $\begin{array}{c}\text { Life } \\
\text { sentence }\end{array}$ & $\begin{array}{c}20 \text {-year } \\
\text { prison }\end{array}$ & $\begin{array}{l}\text { Death } \\
\text { penalty }\end{array}$ & $\begin{array}{c}\text { Life } \\
\text { sentence }\end{array}$ & - & Pending \\
\hline $\begin{array}{l}\text { Tach Due } \\
\text { Thanh } \\
\text { Nguyen }\end{array}$ & $\begin{array}{c}\text { Life } \\
\text { sentence }\end{array}$ & $\begin{array}{l}20 \text {-year } \\
\text { prison }\end{array}$ & $\begin{array}{c}\text { Death } \\
\text { penalty }\end{array}$ & $\begin{array}{c}\text { Life } \\
\text { sentence }\end{array}$ & - & Pending \\
\hline $\begin{array}{l}\text { Renae } \\
\text { Lawrence }\end{array}$ & $\begin{array}{c}\text { Life } \\
\text { sentence }\end{array}$ & $\begin{array}{l}20 \text {-year } \\
\text { prison }\end{array}$ & - & - & - & - \\
\hline
\end{tabular}

During the administration of Yudhoyono, the Indonesian and the Australian governments achieved a good understanding of each other's national interests ${ }^{5}$ and no diplomatic 
protest was issued by the Australian government in relation to the case of Bali Nine. Both governments were aware of the possibility of tensions arising from the arrest and sentencing of the Bali Nine members, therefore, diplomatic actions were taken to dismiss additional pressure on their bilateral relations. Continuous but not overt diplomatic initiatives and responses were taken by both the Australian and Indonesian governments in the Bali Nine case during the administration of Yudhoyono (Nicholson \& Alford, 2010). There was little Australian and Indonesian media coverage on the Bali Nine case during its early period. The media coverage only increased when execution became imminent (Pausacker, 2015).

The Australian government intervened through diplomatic pleas to commute the death sentences of Bali Nine's ringleaders after all the legal avenues were exhausted. After two years of waiting, Jokowi rejected the clemency requests of Chan and Sukumaran. Since the Bali Nine case had lasted for a decade, the bilateral relations between Indonesia and Australia underwent various changes, from neutral to tension, when different national interests were prioritised in their diplomacy on death penalty. There were also changes in the leadership of both countries. The execution of the Bali Nine ringleaders unexpectedly resulted in greater distress in Australia and international communities although this was not the first time for an Australian to be executed for drug trafficking in Southeast Asia. ${ }^{6}$

Following the execution of Chan and Sukumaran, the Australian government withdrew its ambassador to Jakarta, Paul Grigson, for consultations as an immediate diplomatic protest act in response to the execution. The Australian government also suspended all ministeriallevel contacts with Indonesia (Sheridan, 2015). The withdrawal of the ambassador was an unprecedented act. Such protest however, had limited momentum as it only lasted until the return of the ambassador. The withdrawal of the Australian ambassador to Jakarta turned out to be a short-term diplomatic protest as expected by both the Australian and Indonesian communities (Lowy Institute, 2015). The short-term withdrawal of the Australian ambassador to Jakarta undermined the extent of tension in bilateral relations with Indonesia, which weakened the protest to make Indonesia understand the opposition from Australia and the international society (A. Harsono, personal communication, May 11, 2016).

\section{Factors of Indonesia's diplomatic approach to Bali Nine}

Incorporating the data collected from the interviews, the factors affecting the Indonesian diplomatic approach to the Bali Nine case were analysed. Using the theoretical frameworks of realism, statism, and relativism towards human rights and foreign policy as proposed by Donnelly (2013), five factors influencing the Indonesian diplomacy approach to Bali Nine were identified. They were domestic politics and idiosyncrasy, the Indonesian legal system, role of religion, media and public opinion, and Australia-Indonesia relations.

\section{Domestic Politics and Idiosyncrasy}

Jokowi was famously known for his people-oriented policy, in which little attention was paid to the international outlook of Indonesia to have a good reputation in human 
rights. Jokowi pushed for a tougher approach with his people-oriented policy, unlike his predecessor, Yudhoyono who was known as an international player. As the state leader with exclusive authority in Indonesia, Jokowi made his primary obligation to protect his people. During his presidential visits to a few European states, such as Germany, Jokowi reiterated the important use of the death penalty in relation to the emergency status of drug abuse in Indonesia (L. Mandalika, personal communication, July 9, 2016; Amindoni, 2016). This implied that the death penalty was used for protecting the citizens of Indonesia, which was in accord with the realist viewpoint.

The sudden increased use of execution was arguably a political propaganda to construct a strong and decisive image of Jokowi (Dominguez, 2015). Jokowi faced criticisms for being a weak president when he took office in October 2014 without strong military and political backgrounds. Hence, the public announcement of his order for the execution of $14 \mathrm{drug}$ convicts in 2015 served as a proof of his toughness (E. Bayuni, personal communication, January 13, 2016). Jokowi demonstrated his capability in dealing with drug issues in Indonesia by executing foreign drug traffickers. It was anticipated that the tougher image of Jokowi could build up his prestige and popularity in Indonesia.

Furthermore, Jokowi was perceived as being capable of protecting Indonesian sovereignty even when facing pressure from the international community for carrying out the execution. The death penalty has thus, become a necessary political tool for Jokowi to gain public trust in him while protecting national interests. In balance between interests of proceeding and refraining from executing foreign drug convicts, the Jokowi government decided to adhere to national interest in being tough on drugs for political purpose, instead of reconsidering the death penalty based on the grounds of human rights. The primary obligation of a state is to protect its citizens and their interests, in accordance with the realist argument (Vincent, 1998). Hence, the significance of local political interests overshadowed pressure and criticisms from the international community.

\section{Indonesian Legal System}

The death penalty legislation has legalised and justified the legitimacy of practising execution in Indonesia. Capital punishment is listed as one of the basic punishments in Article 10(a) of the Indonesia Penal Code. With the inclusion of capital punishment as part of sentencing in the Indonesia Penal Code, the Indonesian government and the courts were allowed to carry out execution without legal intervention. In the interview with Al Jazeera (2015), Jokowi repeatedly emphasized that death penalty is a positive law. It is therefore, legitimate to carry out execution as permitted by the law. He defended that it was an obligation of a president to uphold and carry out the laws, which should not be interfered by international pressure (Jabour, 2015). As relativist (Donnelly, 2013) argued for the self-determination of a state in regulating its domestic policies, the Indonesian government established the death penalty law for drug-related crimes to protect its national interests.

While there is constitutional consideration on human rights in Indonesia, the Indonesian Constitution and death penalty laws in Indonesia make it harder for human rights advocators 
to challenge the use of the death penalty in Indonesia. For instance, Article 28(A) of the Constitution, states that, "each person has the right to live and the right to defend his life and existence". This is supported by Article 28(I) that stipulates, "the right to life... the fundamental human rights that shall not be curtailed under any circumstance" (Ministry of Foreign Affairs of the Republic of Indonesia). Article 28(I) (4) also stresses that the government is responsible to protect, promote, uphold the full realization of human rights, along with Article 28(I) (5) that requires Indonesia to implement fundamental human rights as a democratic and a law-based state. Article 28(J) however, places obligations on each person to respect others' fundamental human rights, in exchange for exercising his rights and liberties. This has posed further complexity in the human rights of a person in Indonesia as the rights of law breakers are stripped away for failing to fulfil their obligations.

The legal system of Indonesia provides proper legal means for death row convicts to appeal against death sentences. However, the implementation of the legal process is yet to be recognized as fair and capable in practising the death penalty. There were two ongoing legal processes for Chan and Sukumaran at Indonesia's Constitutional Court and the Judicial Commission when they were given 72-hour notices of execution. Chan and Sukumaran launched bribery allegations against the trial judges who allegedly asked for over one million rupiah to deliver a prison sentence of less than 20 years. Later, the original deal was unsuccessful due to pressure from senior legal officials and Indonesian authorities to impose the death penalty. However, the demands for bribe did not cease as they allegedly asked for more money for lesser sentences (Allard, 2015). Such bribery accusation led to the investigation carried out by Indonesia's Judicial Commission to ensure the probity of Indonesian judges (Associated Press, 2015). For instance, Putu Suika and Achmad Yamanie, former judges of the Indonesian Supreme Court, who were in the panels for the case of the Bali Nine ringleaders, were dismissed from the position for receiving bribery in other cases (Bachelard, McKenzie, Topsfield, \& Rosa, 2015). Corruption such as this has undermined the capability of the Indonesian legal system to practise the death penalty.

\section{Role of Religion}

According to Harsono (personal communication, May 11, 2016), Manto (personal communication, May 18, 2016) and Napitupulu (personal communication, May 17, 2016) during the interviews, the death penalty is supported by a majority of the people despite Indonesia having the largest Muslim population in the world. The influence of Islam grew during the post-Suharto period, along with the expansion of the influence and enforcement of Islamic law, which is the Sharia law in Indonesia. Even though the Sharia law is not the principal legislation system in Indonesia, legitimacy of the law is founded on the wide acceptance of the majority Muslim population in Indonesia, particularly supported by radical Muslim groups. However, the majority of Muslims in Indonesia practice their belief moderately, consequently limiting the legislative power of the Islamic law (Lynch, 2009). The Islamic law can serve as a reference for judges during legal proceedings, but not as the main enforced legal system in the civil law-based state. 
According to Mumisa et al. (2015), the death penalty is in conflict with the teaching of the Al-Quran that upholds the right to life of any human being, whereby it is one of the five indispensables of Islam. Deprivation of life can only take place in highly restrictive conditions under the Sharia law, and it is permitted on several crimes, including murder and hudud crimes that are known as claims against God. The law for drug-related crimes is not pre-determined under the Sharia law. It is formed based on independent legal reasoning and jurisdictive decision with reference to the laws on drinking alcohol. Under Ta'zir or claims of the state or society, punishments are delivered based on the discretion of judges in consideration of the social policy and cultural perspectives (Mumisa et al., 2015).

The sentences imposed under Ta'zir could not be more severe than hudud crimes, which reject the application of the death penalty as a choice of sentencing for drug offences. In addition, there is no ijma or general consensus in the practice of the death penalty on drug convicts among the states with Islam as their main religion (Mumisa et al., 2015). However, ijma is subjected to the national interests of each Muslim society, which allows for discrepancy in practising the death penalty. Therefore, the death penalty for drug convicts in Indonesia is a national interest instead of a primary teaching in Islam. The execution of drug convicts by the Jokowi government is fully supported by two largest Muslim organisations in Indonesia, the Nahdlatul Ulama (NU) and the Muhammadiyah (Parlina, 2014). Being legitimised by the religious belief, the normative practice of the death penalty is easily accepted by the Indonesians. The acceptance of the death penalty among the population of Indonesia has turned into an expectation of the Indonesian government to practise the death penalty on drug convicts in accordance with the Islamic law and beliefs.

\section{Media and Public Opinion}

Despite the strong international criticism of the death penalty, the Indonesian government constantly faces local pressure to continue the death penalty practice. For instance, the National Anti-Narcotics Agency of the Republic of Indonesia (BNN) is in opposition to the abolition of the death penalty. The BNN has been advocating for a harsher punishment for narcotics crimes. While their voice was insignificant in the past, the BNN successfully exploited the opportunity in the Meirika Franola case ${ }^{7}$ to advocate stricter punishment on narcotics crimes. This gave rise to new attention on the seriousness of drug issues in Indonesia and the reconsideration of the punishment system for narcotics convicts (McRae, 2015). The rise of anti-drug local organizations such as the militant civil group National Anti-Narcotics Movement (GRANAT), the Anti-Narcotics Movement (GANAS) and the People's AntiAddiction Movement (GERAM) pressured Jokowi's government to execute drug convicts in order to demonstrate its determination and capability in dealing with national drug issues. In labelling drug trafficking as an attack on their Muslim communities, they argued that narcotics had destroyed the younger generation of Indonesia; drug addiction had caused the widespread of HIV and poverty (Nasir, 2012). The existence of local militant anti-drug organisations reflects the strong aversion to drug use and distribution among Indonesians. 
Under the strong propaganda of the Indonesian government, Indo Barometer's poll in March 2015 showed that Indonesians widely supported the execution of drug traffickers on the basis that "narcotics destroy youthful generation". Propaganda against the death penalty is visible in the public spaces of Indonesia. Banners with strong anti-drug slogans such as "Death to all Drug Users and Dealers", "Drugs: Indonesia's number one enemy" and "Destroy drug takers and dealers" could be seen throughout the cities and towns in Indonesia (Nasir, 2012). Public support became a strong factor for the Indonesian government to proceed with the execution. Drug abuse is perceived as one of the most serious crimes by the public. A majority of Indonesians has experienced the negative impacts of drug abuse, either as a victim or a witness of the impacts of drug abuse. It is also widely believed among the locals that a majority of the drugs are imported (Dominguez, 2015).

A few interviewees, including Ricky Gunawan from the Indonesian Legal Aid Foundation (LBH) (personal communication, May 24, 2016) and Putri Kanesia from the Commission for Disapperaed and Victims of Violence (KontraS) (personal communication, May 27, 2016), suggested that the public would be less likely to support the death penalty if they are exposed to the accurate information about the death penalty, such as the unfair trial process and the limited deterrence effect of the death penalty. Public opinion on the death penalty is constructed by the Indonesian government while the justification for the Indonesian government to carry out the execution is based on the need of its people.

\section{Australia-Indonesia Relations}

Due to the geographic proximity, Australia and Indonesia have been closely related to each other strategically and economically. Between 2005 and 2015, the Australian government had four prime ministers, including John Howard (1996-2007), Julia Gillard (2010-2013), Kevin Rudd (2007-2010, 2013) and Tony Abbott (2013-2015). Each of them had different political agenda and national interests during their administration and that brought different diplomatic approaches to Australia's bilateral relations with Indonesia. Bilateral relations between Australia and Indonesia have been up and down during the post-Suharto period, yet their ties remained strong as they acknowledged the importance of their partnership strategically and economically (Clark, 2015). Both countries had been caught in human rights-related incidents, including the humanitarian intervention of East Timor in $1999 .^{8}$ Consistent with the realist (Donnelly, 2013) argument, the realpolitik-based foreign policy maintains the diplomatic relations although tensions arise from human rights issues.

In dealing with the death penalty through the diplomacy conducted between Australia and Indonesia, Howard and Rudd took a pragmatic approach to support the sovereignty of Indonesia and the 'war on drug' policy of Indonesia by supporting the execution of the Bali Nine bombers (Roberts, 2005). Such a move was considered as inconsistent with their abolitionist stance. Therefore, there was a limitation to the long-lasting effects for diplomacy on the death penalty between Indonesia and Australia, which was one of the reasons for the Indonesian government to proceed with the execution of the Bali Nine ringleaders. As 
realists (Smith, 1986) argued that states act based on balancing national interests rationally; the Indonesian government regarded the cost for proceeding with the execution of Chan and Sukumaran was minimal in comparison to the cost of halting the execution.

\section{The Debate between Human Rights and State Sovereignty}

In the Bali Nine case, the Indonesian government viewed external pressure as a threat to its self-determination in formulating and practising its national legislations. From the legal viewpoint, the execution of the Bali Nine ringleaders was abided by Indonesian laws as it was allowed legally at home. In fulfilling the standards of the 'most serious crimes' for the death penalty practice, as stated in Article 6(2) of the ICCPR, Indonesia exercised its discretion as a sovereign state in interpreting drug-related crimes as one of the 'most serious crimes' in Indonesia regardless of its international obligations. Despite being a signatory to the ICCPR, the Indonesian government insisted that the execution was conducted in accordance with its domestic law alone. This shows that the international laws were disregarded. Such action raised a concern in relation to the autonomous interpretation of law that undermines the legitimacy of international law standards (Lynch, 2009). The interpretation of drugrelated crimes as one of the 'most serious crimes' was however, not only consistent with the arguments of Keohane (1986) who argued for the exclusive authority of the states to make their local policies, but also with the notion of diversity of the political system that was presented by relativists (Donnelly, 2013).

International human rights principles have been gradually internalised and incorporated into the states' foreign policies, particularly for democratic regimes as an expression of humanity solidarism with corresponding international actors and an inherent moral obligation towards the own nation (Donnelly, 2013). The inclusion of human rights in the foreign policy was not a 'convenient' task as the nature of the foreign policy and human rights do not coincide with each other. Vincent (1988, p.1) provided the following definitions for human rights and foreign policy:

"Human rights, the rights that all people have by virtue of their humanity, tend to be associated with individuals and if with groups at all then with groups other than states. Foreign policy, which all states have by virtue of their existence in a world of states, ends to be associated only with them."

While it is possible to find a way for human rights and national interests to work together, it is impossible for human rights interests to override national interests in the foreign policy as proposed by Donnelly (2013). He highlighted that the arguments raised against incorporating human rights into the foreign policy were related to the principles of sovereignty and selfdetermination as well as the notion of national interests. He further categorised the viewpoints into three groups: the statist, the relativist and the realist. ${ }^{9}$ While each of the viewpoints has its own strengths and weaknesses, they remain strongly related to the practice of human rights foreign policy, in which inconsistency and trade-off are common. 
Despite the optimism shown by non-state actors towards the growing influence of international human rights standards across geographical boundaries and political entity, the state maintains its inherent authority of sovereignty over resources and territory, including human rights under its territorial jurisdiction (Donnelly, 2013). Foreign policy is established on the notion of sovereign equality that limits the higher authority from interfering with national matters (Hill, 1989). Therefore, states have little power and influence over other states, which indicates non-interference in the domestic affairs of other states. ${ }^{10}$ Meanwhile, the notion of universal human rights principles has challenged the states' jurisdictions when the promotion of individual rights puts the states' morality on trial (Hill, 1989).

Donnelly (2004) argued that sovereignty has been reshaped over time to accommodate the inclusion of human rights promotion. The growing number of states, particularly democratic states, that accept international laws through signing and ratifying various treaties, including human rights-related treaties, could imply that states limit their sovereignty voluntarily with external obligations. The first approach, as proposed by Donnelly (2004), is the statists. For statists, states have exclusive sovereignty with regards to domestic policies and international relations with centralized executive authority based on their own rule of law (Arendt, 1966). There should not be any external pressures or internal limitations in restraining states from ruling within its boundaries based on political interests. The fact that the international law system, including the mechanisms available in promoting human rights, remains weak could indicate the reluctance of states to surrender their sovereignty (Donnelly, 2013). Therefore, the human rights objective is not a moral obligation in the foreign policy. It is a national interest to fulfil political objectives.

Donnelly (2013) also suggested that some instruments adopted in the foreign policy such as diplomatic representation should not be considered as intervention in other state's domestic affairs because such diplomatic instruments are applicable to other foreign policy's objectives. It implies that international action on behalf of human rights will only be considered as intervention when the approach is illegitimate and unusual compared to similar cases of human rights violation. Nevertheless, states that violate human rights also employ diplomatic representations when they stand against other states on the matter of human rights. Such approach is conflicting and it brings into question the significance of an international action in representing human rights as an intervention. The relationship between sovereignty and human rights in a statist's argument remains paradoxical where both seem to be incompatible yet co-exist.

The second approach is the realists. The realists argue strongly against the inclusion of human rights in the foreign policy because it is not feasible to pursue moral obligations in an anarchic-based international system. As national interests are based on power alone, human rights become an obstacle for states to achieve other national interests in a foreign policy (Morgenthau, 1954). For realists, the focus of the foreign policy is strategic interests that strengthen national power. Human rights policy jeopardizes the international relations as it is in conflict with other national interests (Baehr \& Castermans-Holleman, 2004; Forsythe, 2006). The notion of human rights is perceived as an ideal morality for interpersonal 
relations rather than international relations. In other words, states would not abandon their realpolitik interests in other states just because of the substandard human rights practice in other states.

The arguments raised by realists are consistent with the nature of the foreign policy that operates based on the principle of balancing national interests. A foreign policy conveys the interests of a state, which include multiple conflicting goals (Donnelly, 2013). In cases where states act in accordance with international human rights principles, it involves the notion of raison d'etat ${ }^{11}$ instead of the basis of morality alone (Vincent, 1988). States act primarily based on their interests through rational analysis. It is purely a matter of balance between national interests, in which the weightage assigned to human rights interests is in comparison with others (Smith, 1986). States evaluate the importance of the different national interests involved and act in accordance with whichever national interest that would be essential to the state's survival in that particular circumstance. In an anarchybased international system, morality and law are placed subordinate to power and state interests (Schwarzenberger, 1951). Therefore, for realists, it is plausible to practise human rights in a foreign policy inconsistently, like other national interests, as the values set on each national interest are subject to each circumstance.

The third approach provided by the relativists argues that states should be allowed to decide on its own in matters related to self-determination or in promoting international human rights standards without external interference (Donnelly, 2013). States should respect the independency of each other based on state sovereignty and non-intervention in order to maintain international order (Bull, 2002). The political and social regulation of a state should be solely under the jurisdiction of a state, where other states have no say. Any external pressure and action that attempts to influence or change the state decision are considered as intervention in domestic affairs. Likewise, the imposition of international human rights standards by external pressure is regarded as an act of moral imperialism for relativists. If there is any desire for human rights improvement, changes should take place from within the state itself instead of external intervention. While it is inevitable for states to step in occasionally into other states' domestic matters as it is inherent in the relations between states, relativists highlight the need for respecting the diversity of the political system and the cultural values for greater independency in the sovereignty of the states (Donnelly, 2013).

Human rights are perceived as a challenge to the exclusive political and legal authority of the states embedded in state sovereignty. As a non-structuralised institution, state sovereignty is at the foundation of institutional regulations governing political and territorial boundaries. The debate on the formation and sources of authority for sovereignty has taken place. In terms of external sovereignty, the boundaries of state sovereignty have been eroded with growing obligations and accountability towards other states in terms of human rights. On the other hand, the growing legal authority of individuals in challenging their governments also reduces the exclusiveness of the state's authority within its territorial boundaries (Clunan, 2009). This is reflected in the ongoing debates between the abolitionists and the retentionists. 
Putting the theoretical argument into the case of Bali Nine, the Indonesian government has repeatedly used the argument of sovereignty to fend off international criticisms on its death penalty practice. Jokowi put up two main justifications in defending the use of the death penalty in Indonesia during an interview with Al Jazeera (2015); first, the legal practice of the death penalty in the Indonesian jurisdiction system, and second, Indonesia's national interests of protecting citizens from drug abuse. Jokowi focused only on Indonesia's national interests in being self-determined when practising laws, without giving in to external pressures. Jokowi warned other countries not to interfere in Indonesia's internal affairs on the death penalty because it was about the sovereignty of Indonesia's law, and asked for respect to its sovereignty as a state and nation (A. Manto, personal communication, May 18, 2016). This is consistent with statists' stance for states to be entities with exclusive authority within its territorial boundaries (Donnelly, 2013).

While the three approaches of the statists, realists and relativists argue for the incompatibility of human rights and foreign policy based on different basis, they shared a common disagreement, that is, the promotion of human rights as the main interest in the foreign policy. As a state party to the ICCPR, Indonesia has its own understanding and interpretation of the notion of 'most serious crimes' on practising the death penalty for drug-related crimes. Even though Indonesia insists on the legality of the death penalty in relation to the human rights treaties that it was obliged to, the discrepancy in practising international human rights standards that are subjected to the discretion of the state led to diplomatic issues.

The notion of nationalism embedded in Indonesian politics was reflected strongly in the response of the Indonesian government in the Bali Nine case to defend the primacy of its national interests, including the protection of its citizens and the sovereignty of Indonesia. The concept of Indonesian nationalism was derived from the independence of Indonesia as a sovereign state after the Dutch colonization. The strong devotion to the state among the citizens has opposed any ideas and external interferences that would undermine the sovereignty of states, or depict Indonesia in a subordinate position. With the strong nationalistic sentiment in Indonesia, the majority perceived Australian diplomatic efforts as a form of interference and impudence to Indonesia's sovereignty in practising justice, according to relativists (Donnelly, 2013). Overt diplomatic appeals even worsened the situation (Dominguez, 2015).

\section{Conclusion}

This paper is grounded on Jack Donnelly's argument in terms of human rights and national interests, focusing on the sovereignty of states in the diplomatic context. It discusses the Indonesian government's diplomatic approach to the death penalty issue, outlined in the background context of the Bali Nine case, analyses the diplomatic initiatives and responses taken by both the Australian and the Indonesian governments, and identifies the factors affecting the diplomatic approach of the Indonesian government to the case. Five factors influencing the Indonesian diplomatic approach to Bali Nine are identified. They are the 
domestic politics and idiosyncrasy, the Indonesian legal system, the role of religion, media and public opinion, and the Australia-Indonesia relations.

The main finding in this paper shows that the tough diplomacy approach of the Indonesian government was pragmatic-based. It suggests that human rights interests were subordinated to other national interests in balancing the objectives of Indonesia's diplomatic approach to the drug-related death penalty practice. The gains are higher for the execution as compared to the costs, in terms of security and economy interests as well as its international relations. To this end, the Indonesian government dismissed any possible extensive impacts of the execution on the bilateral relations between Indonesia and Australia. Consistent with the realist argument, the realpolitik-based foreign policy maintained the diplomatic relations although tensions arose from human rights issues (Donnelly, 2013).

The Bali Nine case has certainly impacted the Indonesian foreign policy to some extent as there was never a similar case that resulted is strong international criticisms and pressures on the use of the death penalty in Indonesia. However, these impacts led to neither any significant changes in the death penalty practice in Indonesia nor any positive move towards the abolition of the death penalty laws. Without international actions that were strong enough to threaten or surpass national security interests, the Indonesian government could easily focus on practising its execution of drug convicts without the concern of international pressure. The lack of external pressure boosted the self-determination of Indonesia as to whether or not to pursue human rights interests, which also supported the statist argument that the state acts as an exclusive actor in governing its domestic affairs (Keohane, 1986).

The death penalty practice in Indonesia showed a competing interest between the international community and local citizens. Strong opposition was demonstrated against Western notions of human rights that focused on individual rights. Such human rights were regarded as a threat to national interests in the Bali Nine case when both individual and state interests were in conflict. While Donnelly (2013) argued there is a possibility for human rights to play a minor role in foreign policy, it could however, be easily disregarded for a bigger objective in protecting national interests and ensuring state survival. Instead of looking for a way of coexistence between national security and human rights interests, the Jokowi government dismissed the possibility of advocating human rights principles in the Bali Nine case. Hence, the rejection of the clemency pleas of Chan and Sukumaran were an approach to protect Indonesia's sovereignty and national interests, in which no moral or human rights concerns were involved, as realists argued that there was no place for human rights in the foreign policy (Morgenthau, 1954).

The inclusion of human rights in the objectives of the Indonesian foreign policy does not carry significant weight in influencing Indonesia's diplomatic approach to the death penalty. The Indonesian government strived to maintain its sovereignty, self-determination and other national interests in the matter of the death penalty. External pressure was viewed as a threat to its self-determination in formulating and practising its national legislations. Despite being a signatory to the ICCPR, the Indonesian government insisted that the execution was 
subjected to their domestic law alone and thus disregarded the international laws. Such action raised a concern in relation to the autonomous interpretation of the law that undermined the legitimacy of international law standards (Lynch, 2009). The interpretation of drug-related crimes as one of the 'most serious crimes' was consistent with the arguments of Keohane (1986) who argued for the exclusive authority of states to make their local policies, and the notion of diversity of the political system that was presented by the relativists (Donnelly, 2013).

In essence, this paper concludes that the death penalty remains as a sovereign issue, involving the promotion of national interests in Indonesia and preventing intervention from other states and international actors. The Yudhoyono and Jokowi governments emphasised greatly the need for the death penalty to curb local epidemic drug issues, to the extent of reflecting it in its foreign policy through dismissing any international criticisms of the death penalty in Indonesia. The death penalty in Indonesia should be solely the jurisdiction of Indonesia, and any changes on it should come from local pressure and demands, as argued by Donnelly (2013). The question is no longer about how Indonesia balances its national interests and promotes human rights in its foreign policy in relation to the death penalty issue; instead, the question is how to take into consideration the cooperation between the international community and the local advocators in limiting the death penalty practice. While there is no positive outlook for the abolition of the death penalty in Indonesia in the near future, human rights and state sovereignty could co-exist provided there was strong local public support for the abolition of the death penalty.

\section{Acknowledgement}

This research received no specific grant.

\section{References}

AAP. (2006, April 27). Bali Nine duo left out as sentences cut. Retrieved from The Sydney Morning Herald: http://www.smh.com.au/news/world/bali-nine-life-sentencescut/2006/04/27/1145861461977.html?page=fullpage\#contentSwap 1

AAP. (2011, January 31). Bali Nine pair Andrew Chan and Myuran Sukumaran may be spared death penalty. Retrieved from Herald Sun: http://www.heraldsun.com.au/ news/bali-nine-pair-andrew-chan-and-myuran-sukumaran-may-be-spared-deathpenalty/story-e6frf7jo-1225997195766

Afriansyah, A. (2015, April 27). Indonesia does need the death penalty to deter drug traffickers. Retrieved from The Conversation: http://theconversation.com/indonesiadoes-need-the-death-penalty-to-deter-drug-traffickers-37853

Allard, T. (2015, April 27). 'They wanted \$130,000 ... and then more': explosive Bali Nine bribe allegations. Retrieved from The Sydney Morning Herald: http:/www. smh.com.au/world/they-wanted-130000--and-then-more-explosive-bali-nine-bribeallegations-20150426-1mtwc1.html 
Al Jazeera. (2015, March 9). Will Indonesia execute a mentally ill Brazilian? Retrieved from Al Jazeera: http://www.aljazeera.com/indepth/features/ 2015/03/indonesiaexecute-mentally-ill-brazilian-150309054107050.html

Amnesty International Global Report: Death Sentences and Executions 2018. Retrieved from Amnesty International: https://www.amnesty.org/en/documents/act50/9870/2019/en/

Arendt, H. (1966). The origins of totalitarianism. New York, NY: Harcourt, Brace \& World.

Associated Press. (2015, April 28). Australia wants corruption claims against judges investigated before Bali Nine pair executed. Retrieved from Television New Zealand: https://www.tvnz.co.nz/one-news/world/australia-wants-corruption-claims-againstjudges-investigated-before-bali-nine-pair-executed-6302186

Bachelard, M., Mckenzie, N., Topsfield, J., \& Rosa, A. (2015, February 12). Two Bali nine judges sacked for corruption, manipulation. Retrieved from The Sydney Morning Herald: http://www.smh.com.au/world/two-bali-nine-judges-sacked-for-corruptionmanipulation-20150211-13btyd.html

Baehr, P. R., \& Castermans-Holleman, M. (2004). The role of human rights in foreign policy (3rd ed.). Hampshire: Palgrave Macmillan.

Basuki, T., Dwifatma, A., Fransiska, A., \& Sulaiman, Y. (2015, April 29). Bali Nine duo executed: The view from Indonesia. Retrieved from The Conversation: https:// theconversation.com/bali-nine-duo-executed-the-view-from-indonesia-38392

Bull, H. (2002). The anarchical society: A study of order in world politics. Hampshire: Palgrave.

Clark, H. (2015, August 10). Australia and Indonesia: Business as usual? Retrieved from The Diplomat: https:/thediplomat.com/2015/08/australia-and-indonesia-businessas-usual/

Clunan, A. L. (2009). Redefining sovereignty: Humanitarianism's challenge to sovereign immunity. In N. Shawki \& M. Cox (Eds.), Negotiating sovereignty and human rights: Actors and issues in contemporary human rights politics (pp 7-26). Surrey: Ashgate Publishing Limited.

Coca, N. (2015, March 3). Indonesia's death penalty hypocrisy. Retrieved from The Diplomat: http://thediplomat.com/2015/03/indonesias-death-penalty-hypocrisy/

Dominguez, G. (2015, January 20). Why didn't Indonesia's Jokowi stop the execution of drug traffickers? Retrieved from Deutsche Welle: http://www.dw.com/en/why-didntindonesias-jokowi-stop-the-execution-of-drug-traffickers/a-18202078

Donnelly, J. (2004). State sovereignty and human rights (HRHW Working Paper No. 21).

Donnelly, J. (2013). Universal human rights in theory and practice (3rd ed.). New York, NY: Cornell University.

Forsythe, D. P. (2006). Human rights in international relations (2nd ed.). Cambridge, CB: Cambridge University Press.

Forsythe, D. P. (2011). Human Rights . American Political Science Association (APSA) Annual Meeting Paper. Seattle.

Hill, D. (1989). Human rights and foreign policy: Theoretical foundations. In D. M. Hill (Ed.), Human rights and foreign policy: Principles and practice (pp. 3-20). New York, NY: Palgrave Macmillan. 
Imparsial. (2010). Inveighing against death penalty in Indonesia. Jakarta: Imparsial. International Commission against the Death Penalty. (2013). The death penalty and the "most serious crime": A country-by-country overview of the death penalty in law and practice in retentionist states. Retrieved from http:/www.icomdp.org/cms/wpcontent/uploads/2013/02/Most-serious-crimes_final_6Feb2013.pdf

Jabour, B. (2015, May 10). Joko Widodo defends death penalty as 'positive' for Indonesia. Retrieved from The Guardian: http://www.theguardian.com/world/2015/may/10/ joko-widodo-defends-death-penalty-as-positive-for-indonesia

Krasner, S. (1999). Sovereignty: Organized hypocrisy. Princeton, NJ: Princeton University Press.

Lowy Institute. (2015). 2015 Lowy Institute polling: Indonesia and the death penalty. Sydney: Lowy Institute for International Policy.

Lynch, C. (2009). Indonesia's use of capital punishment for drug-trafficking crimes: Legal obligations, extralegal factors, and the Bali Nine case. Columbia Human Rights Law Review, 40, 523-593.

McRae, D. (2015, January 29). From the archive: Staying the executioners'. Retrieved from Inside Indonesia: http://www.insideindonesia.org/index.

Ministry of Foreign Affairs of the Republic of Indonesia. (n.d.). The Constitution of the Republic of Indonesia of 1945.

Morgenthau, H. (1954). Politics among nations: The struggle for power and peace (2nd ed.). New York, NY: Alfred A. Knopf.

Mumisa, M. (2015). Sharia law and the death penalty: Would abolition of the death penalty be unfaithful to the message of Islam? London: Penal Reform International.

Nasir, S. (2012). Drug policy in Indonesia, law amendments but punitive approach remains.

Nicholson, B., \& Alford, P. (2010, October 22). Minister raises plight of Schappelle Corby and Bali Nine with Indonesia. Retrieved from The Australian: http://www. theaustralian.com.au/news/world/minister-raises-plight-of-schappelle-corby-andbali-nine-with-indonesia/story-e6frg6so-1225941956467

Parlina, I. (2014, December 26). Muslim organizations support death penalty. Retrieved from The Jakarta Post: https://www.thejakartapost.com/news/2014/12/26/muslimorganizations-support-death-penalty.html

Pausacker, H. (2015, November 8). Press representation of the 'Bali Nine' in Indonesia and Australia. Retrieved from Inside Indonesia: http://www.insideindonesia.org/pressrepresentation-of-the-bali-nine-in-indonesia-and-australia

Phipps, C. (2015, April 28). Who were the eight people executed by Indonesia? Retrieved from The Guardian: https:/www.theguardian.com/world/2015/apr/29/bali-nine-whoare-the-nine-people-being-executed-by-indonesia

Roberts, J. (2005, May 11). Howard government leaves "Bali Nine" alleged drug runners to their fate. Retrieved from World Socialist Web Site: https://www.wsws.org/en/ articles/2005/05/bali-m11.html

Schwarzenberger, G. (1951). Power politics: A study of international society (2nd ed.). New York, NY: F. A. Praeger. 
Sheridan, G. (2015, May 2). Bali 9 executions: Joko Widodo ignored deputy, SBY and rival. Retrieved May 16, 2016, from The Australian: http://www.theaustralian.com.au/ news/nation/bali9executionsjokowidodoignoreddeputysbyandrival/newsstory/0910f $140 \mathrm{a} 7036 \mathrm{a} 1 \mathrm{fb} 2 \mathrm{f} 108 \mathrm{e} 9 \mathrm{faea} 5116$

Simandjuntak, D. (2015). Spectacle of the scaffold? The politics of death penalty in Indonesia. ISEAS Perspective, 1-8.

Smith, M. J. (1986). Realist thought from Weber to Kissinger. Baton Rouge, LA: Louisiana State University Press.

The Guardian. (2015, January 18). Six drug convicts executed in Indonesia, including five foreigners. Retrieved from The Guardian: https://www.theguardian.com/world/2015/ jan/18/indonesia-six-drug-convicts-shot-dead-five-foreigners

Vincent, R. J. (Ed.). (1988). Foreign policy and human rights: Issues and responses. Cambridge, CB: Cambridge University Press. 


\section{Endnotes:}

1 For instance, Article 28A emphasizes, "Each person has the right to live and the right to defend his life and existence".

2 For more information on massacre and mass violence during the administrations of Sukarno and Suharto, see: Jetchke, A. (2010). Human rights and state security: Indonesia and the Philippines. Philadelphia, PA: University of Pennsylvania Press; Mcgregor, K. (2013). Mass violence in the Indonesian Transition from Sukarno to Suharto. Global Dialogue, 1-12.

In responding to the execution of Ruyati binti Sapubi in Saudi Arabia, the Indonesian government withdrew its ambassador to Riyadh, imposed moratorium on ending domestic workers to Saudi Arabia, established a special task force for 23 Indonesian migrant workers who were on death row in Saudi Arabia, and released public criticism of the Saudi Arabia government.

The Second Optional Protocol to the ICCPR was adopted with the objective of abolishing the death penalty worldwide, particularly among the participating states' territories.

In an interview with Southern Cross Radio, Howard expressed his understanding of Yudhoyono's obligations to his people. Howard said, "When it comes to the crunch his (Yudhoyono's) obligation to his own people and to the strength of the domestic campaign against drugs is far greater and more important than his closeness to and friendship with me. And so it ought to be" (Head, 2006).

A majority of Australians supported the death penalty for Van Nguyen who was sentenced to death in Singapore for drug trafficking on 2 December 2005 (Morgan poll, 2005).

7 Meirika Franola was originally sentenced to death in 2000 but received clemency from Yudhoyono in 2012. She was re-arrested by BNN in 2013 at the Tangerang women's prison for a narcotics crime. Her clemency was revoked and the death penalty was reinstated.

8 In 1999, Australia led a humanitarian intervention in East Timor, following an outbreak of violence by the militia with the support of the Indonesian National Armed Forces against East Timorese.

9 There are four types of sovereignty: international legal sovereignty, Westphalian sovereignty, domestic sovereignty, and interdependence sovereignty. This study focuses on Westphalian sovereignty and international legal sovereignty that involveds the issues of authority and legitimacy of the states. According to Krasner (1986), Westphalian sovereignty is referred to as, "a political organization based on the exclusion of external actors from authority structures within a given territory" while international legal sovereignty concerns "the practices associated with mutual recognition, usually between territorial entities that have formal juridical independence."

"The principle of non-intervention identifies the rights of states to sovereignty as a standard in the international society and makes explicit the respect required for it in abstention from intervention (Vincent, 1974)."

11 Raison d'etat, translated as "reason of state", argues for whatever is good for the state and not morality or norms. In emphasizing power and interest, realists deny the relevancy of morality in politics and assert that every means, either moral or immoral, is acceptable to attain certain political ends. 